\title{
The Use of 2-Chloroethanol for Reversible Depolymerisation of the Protein Shell of Bacteriophage fr
}

\author{
D. SChUbert ${ }^{*}$ and H. Frank \\ Max-Planck-Institut für Virusforschung, Tübingen, Germany \\ (Z. Naturforsch. 25 b, 711-713 [1970]; eingegangen am 27. April 1970)
}

\begin{abstract}
In mixtures of 1 volume of buffer and 2 volumes of 2 -chloroethanol, the icosahedral bacteriophage fr is split into RNA and monomeric protein subunits. After removal of the RNA and after replacement of the organic solvent by water, viruslike particles can be obtained by dialysis of the protein against neutral buffers of high ionic strength, whereas multishell particles are formed in buffers of low ionic strength. All results achieved by the use of 2-chloroethanol are very similar to those obtained using acetic acid.
\end{abstract}

A number of methods is known for the splitting and subsequent reaggregation of the rodlike tobacco mosaic virus (TMV ${ }^{1}$. Reversible depolymerisation of icosahedral viruses has been more difficult to achieve. The reason for this seems to be that the protein shell of most icosahedral viruses is very stable. Thus splitting of the shell normally leads to severe denaturation of the protein, adding to the problem of reassembly the problem of renaturation ${ }^{2}$. Therefore, up to now, satisfying results concerning the reversible depolymerisation of spherical viruses have been obtained only by two methods; for small RNA bacteriophages ${ }^{3-5}$ by FraENKELConRAT's acetic acid method ${ }^{6}$ and for a group of closely related, small plant viruses ${ }^{7,8}$ by exposing them to high salt concentrations. It is obvious that the addition of further methods would be advantageous because it would offer further possibilities for the study of the physico-chemical principles of virus structure and of protein-protein and proteinnucleic acid interactions. We have tried to achieve this aim using bacteriophage fr, the first spherical virus for which self-assembly of protein subunits in the absence of nucleic acid was shown ${ }^{5}$. It turned out that with this virus reversible depolymerisation of the protein coat using 2-chloroethanol can be performed as effectively as by the use of acetic acid.

* Present address: II. Physiologisches Institut, Universität des Saarlandes, 665 Homburg (Saar), Germany.

1 D. L. D. Caspar, Advances Protein Chem. 18, 37 [1963].

2 D. Schubert, Biochim. biophysica Acta [Amsterdam] 188, 147 [1969].

3 T. Suigiyama, R. R. Herbert, and K. A. Hartmann, J. molecular Biol. 25, 455 [1967].

4 T. Hoнn, European J. Biochem. 2, 152 [1967].

\section{Materials and Methods}

\section{Reversible depolymerisation of the protein shell}

The method used is analogous to the acetic acid method $^{6,2}$ and similar to the procedure described by Chien et al. ${ }^{9}$ for tobacco mosaic virus. In an ice bath, 2 volumes of 2-chloroethanol (Merck, Darmstadt) were added to one volume of $0.15 \mathrm{M} \mathrm{NaCl}, 0.02 \mathrm{M}$ Tris-HCl, $\mathrm{pH} 7.2$, containing $10-25 \mathrm{mg}$ fr (grown and purified as described before ${ }^{2}$ ). After 60 min the virus RNA had precipitated and was removed by centrifugation (30 min at $3000 \mathrm{rpm}$ in a Stock centrifuge). The supernatant was then diluted with an equal volume of $\mathrm{H}_{2} \mathrm{O}$, and the solution was dialyzed extensively against $\mathrm{H}_{2} \mathrm{O}$. Afterwards, $0.02 \mathrm{M} \mathrm{NaOH}$ was added until the $\mathrm{pH}$ of the solution was between 7.0 and 7.5. The final step of the procedure was dialysis of the sample against buffers of varying ionic strength in the neutral $\mathrm{pH}$ range. All centrifugations and dialyses were carried out at $4{ }^{\circ} \mathrm{C}$. - Essentially the same results were obtained if, after centrifugation, the buffer-2-chloroethanol mixture was dialysed first against $33 \%$ acetic acid and then against $\mathrm{H}_{2} \mathrm{O}$, or if the mixture was dialysed against $\mathrm{H}_{2} \mathrm{O}$, without preceding dilution with $\mathrm{H}_{2} \mathrm{O}$.

\section{Ultracentrifugation}

Ultracentrifugation was performed in a Spinco model $\mathrm{E}$ analytical ultracentrifuge equipped with monochromator, photoelectric scanning system and multiplexer accessory. An An-F rotor was used for the measurements. Rotor temperature was between 18 and $22{ }^{\circ} \mathrm{C}$; during runs it was kept constant within $\pm 0.2{ }^{\circ} \mathrm{C}$. The monochromator was set to wavelengths between 280 and $300 \mathrm{~m} \mu$, depending on protein concentration.

5 R. Herrmann, D. Schubert, and U. Rudolph, Biochem. biophysic. Res. Commun. 30, 576 [1968].

6 H. Fraenkel-Conrat, Virology 4, 1 [1957].

7 J. B. BANCROFT and E. Hiebert, Virology 32, 354 [1967].

8 J. B. BANCROFT, C. E. Bracker, and G. W. WAGner, Virology 38, 324 [1969].

9 Y. J. Chien, Y. S. Chang, and T. C. Tsao, Scientia Sinica Peking 14, 610 [1965]. 
For measurement of sedimentation coefficients, double sector cells with filled-Epon centerpieces were used. Rotor speed was $40000 \mathrm{rpm}$. Sedimentation velocity was determined from the movement of the point corresponding to half the optical density between the plateau regions, and corrections to standard conditions were applied using the data on buffer viscosity and density tabulated by ELIAS ${ }^{10}$. - Sedimentation equilibrium runs with protein dissolved in one volume $0.15 \mathrm{M} \mathrm{NaCl}, 0.02 \mathrm{M}$ Tris- $\mathrm{HCl}$ and two volumes 2-chloroethanol were performed at $26000 \mathrm{rpm}$ using normal single sector aluminium centerpieces and polyethylene gaskets. Molecular weight was computed from the equation ${ }^{10}$

$$
M=\frac{2 R T}{(1-\bar{v} \varrho) \omega^{2}} \cdot \frac{\Delta \ln C}{\Delta\left(x^{2}\right)} .
$$

As in calculations of $s_{20, \mathrm{w}}$, a value of $0.735 \mathrm{ml} / \mathrm{g}$ was used for the partial specific volume of the protein ${ }^{11}$, and for the solvent density, $Q=1.1143 \mathrm{~g} / \mathrm{ml}$ was obtained from density measurements.

\section{Other methods}

Electron microscopy using negative staining technique with $1 \%(\mathrm{w} / \mathrm{v})$ uranyl-acetate, $\mathrm{pH} 4.4$, or $2 \%(\mathrm{w} / \mathrm{v})$ phosphotungstic acid $(\mathrm{pH} 7.2)$ was performed with a Siemens Elmiskop I a. A detailed description of the staining procedure and a discussion of possible staining artefacts was given recently ${ }^{12}$. Ultraviolet absorbance was measured in a Zeiss MQ III spectrophotometer. Protein concentration was determined by measuring the ultraviolet absorbance using an extinction coefficient $l_{1 \mathrm{~cm}}^{1 \%}=12.3$ for the long-wavelength maximum of the protein absorption spectrum ${ }^{2}$ (no correction for light scattering and for influence of protein conformation on the extinction coefficient was applied).

\section{Results}

\section{Effect of 2-chloroethanol on fr virus}

During treatment of the virus solution with 2-chloroethanol, a white precipitate appears. If this precipitate is removed by centrifugation, the clear supernatant has a typical protein ultraviolet absorption spectrum $\left(\lambda_{\max }=278 \mathrm{~m} \mu\right)$ with an absorbance ratio $A_{260 \mathrm{~m} u} / A_{280 \mathrm{~m} \mu}=0.59-0.61$. This shows that the solution contains almost pure fr protein. Assuming that the value of $A_{260 \mathrm{~m} u} / A_{280 \mathrm{~m} u}$ for pure protein is not markedly different for protein dissolved in the buffer-2-chloroethanol mixture and for protein in $33 \%(\mathrm{v} / \mathrm{v})$ acetic acid, the content of

10 H. G. Elias: Ultrazentrifugen-Methoden, $2^{\text {nd }}$ ed. BecKMAN, Instruments GmbH, München 1961.

11 L. R. Overby, G. H. Barlow, R. H. Doi, M. Jacob, and

S. Spiegelman, J. Bacteriol. 92, 739 [1966].

12 D. Schubert and H. Frank, submitted to Virology.
RNA impurities in the mixture can be calculated to be around $0.1 \%$ of the protein weight ${ }^{2}$. About $70 \%$ of the protein are found in the supernatant. At protein concentrations of $2.0 \mathrm{mg} / \mathrm{ml}$, measurements in the ultracentrifuge using the sedimentation equilibrium method yielded an apparent molecular weight $M_{\text {app }}=13200$. Though uncertainties arise from missing knowledge of the correct value for the partial specific volume and of the influence of nonidealities of the solution, it is unlikely that the true value for the molecular weight differs from this value by more than \pm 10 per cent. Thus, the molecular weight of the protein in the buffer-2-chloroethanol mixture agrees well with the molecular weight of the protein subunit, as determined by chemical analysis ${ }^{13}$. The absence of intact virus shells or of other high molecular weight aggregates in the mixture was also demonstrated by electron microscopy.

These results clearly show that the effect of 2 -chloroethanol on $\mathrm{fr}$ virus and fr coat protein is very similar to the effect of acetic acid. Especially, the reagent can be as effectively used as acetic acid to prepare monomeric protein subunits practically free of nucleic acid in a high yield.

\section{Final products of the aggregation process}

Not only the first step of the process under investigation leads to results similar to those obtained by the acetic acid method, but also the last step which is dialysis of the protein dissolved in very dilute $\mathrm{NaOH}$ against nearly neutral buffers. Depending on the ionic strength of the buffers, two types of aggregates could be observed, in agreement with the results described for protein prepared by the acetic acid method ${ }^{12,14}$.

a) Aggregation at highionic strength: Aggregates which were obtained after dialysis of the protein against $1.0 \mathrm{M} \mathrm{NaCl}, 0.02 \mathrm{M}$ phosphate buffer, $\mathrm{pH}$ 7.6, and which are representative for those obtained after dialysis against various buffers with ionic strengths between 0.5 and 2.0 and $\mathrm{pH}$ values between 7.0 and 8.5 are shown in fig. $1^{*}$. These particles are spherical in shape and similar to virus particles; their diameter is, within the limits of er-

13 B. Wittmann-Liebold, Z. Naturforsch. 21 b, 1249 [1966]. 14 D. Schubert and H. Frank, Hoppe-Seyler's Z. physiol. Chem. 351, 130 [1970].

* Figs. $1-4$ see table p. 712 a. 
D. Schubert and H. Frank, The Use of 2-Chloroethanol for Reversible Depolymerisation of the Protein Shell of Bacteriophage fr (p. 711)
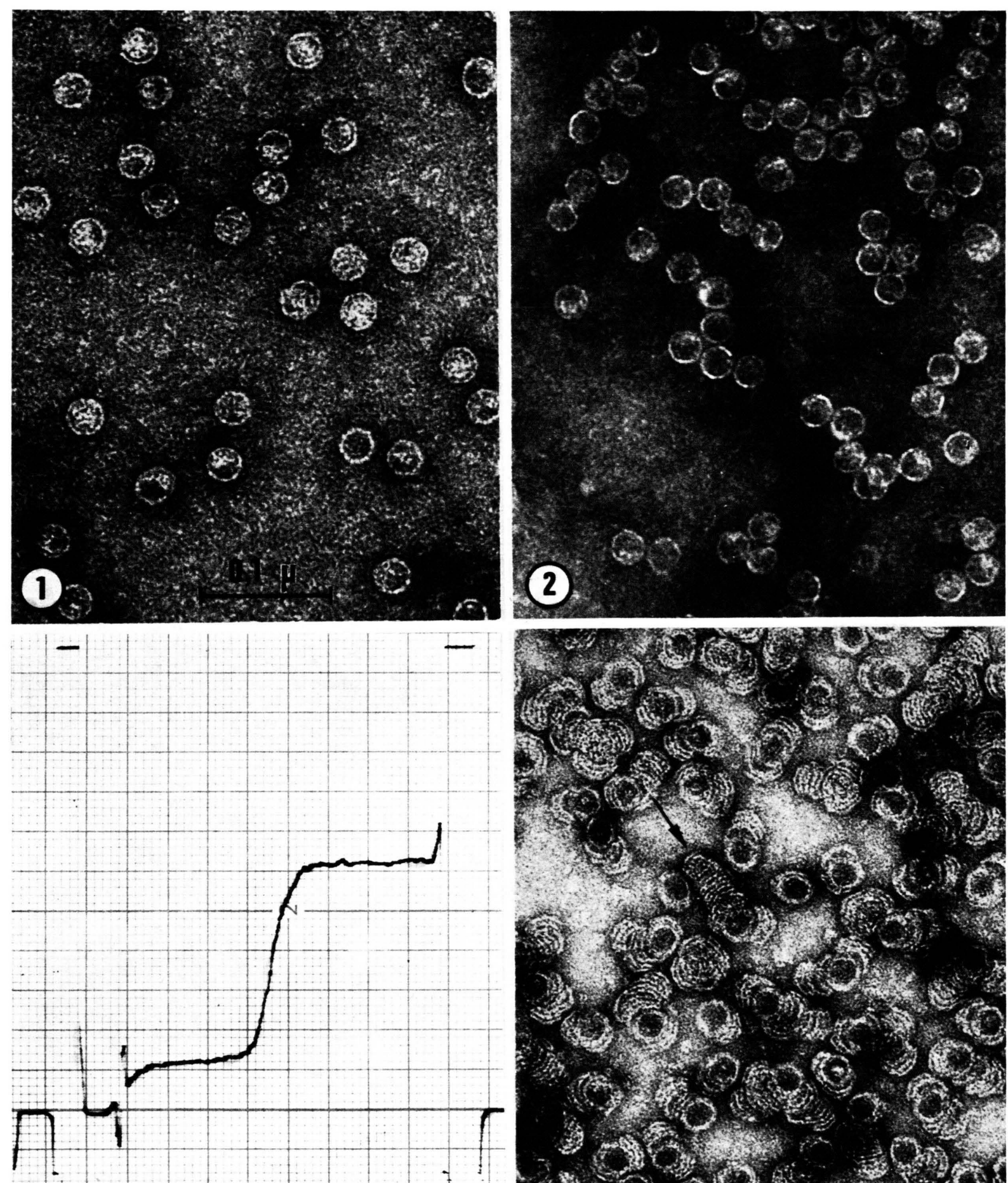

(3) $\quad 1: 3$

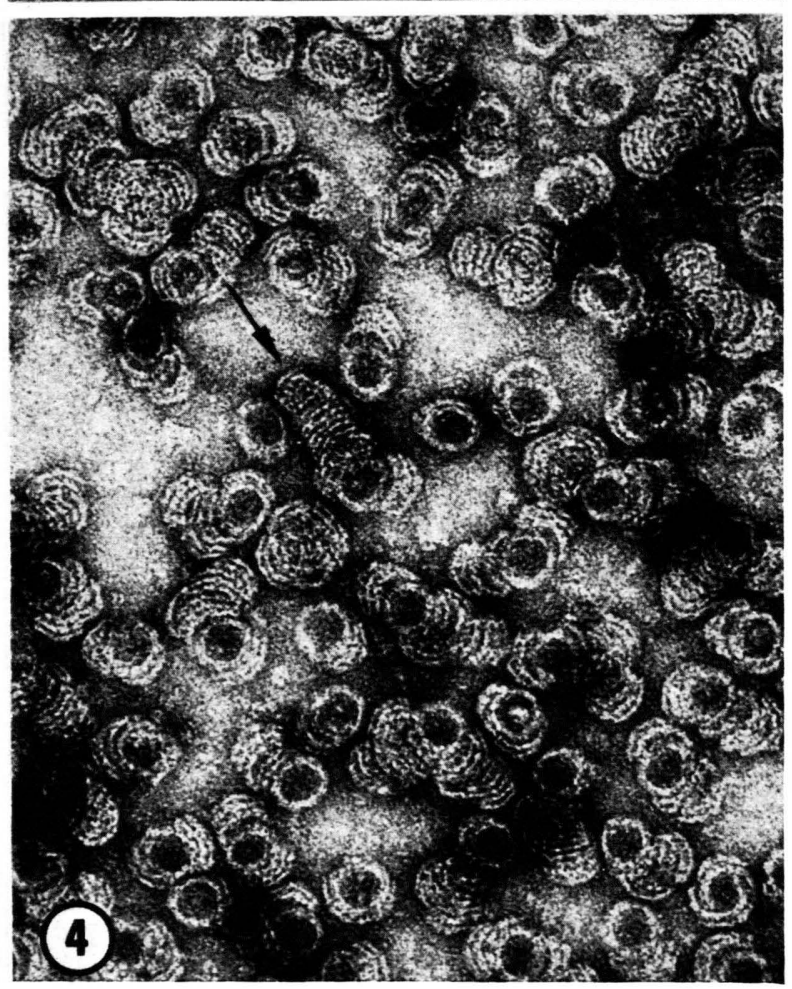



ror, equal to that of fr virus. As can best be seen from electron miicrographs obtained after negative staining with $2 \%(\mathrm{w} / \mathrm{v})$ phosphotungstic acid (fig. 2 ), the particles do not contain a compact protein core but are empty shells, corresponding to those aggregates which can be prepared from virus particles by degradation of the nucleic acid. The yield of the reaggregation process is very high: for freshly prepared protein and protein concentrations between 1.0 and $2.0 \mathrm{mg} / \mathrm{ml} 60-90 \%$ of the protein is found in the high molecular weight aggregates. This is well demonstrated by fig. 3 , which shows the sedimentation behaviour of the samples. Fig. 3 also shows that stable intermediates with $s$-values between that of the virus-like particles and that of the low molecular weight fraction (probably monomer) do not occur under these conditions. The sedimentation coefficient $s^{0}{ }_{20, w}$ of the virus-like particles was determined to be $55.5 \pm 1.5$.

b) Aggregation at low ionic strength: As for protein prepared by the use of acetic acid $^{12,14}$, at protein concentrations $c>0.5 \mathrm{mg} / \mathrm{ml}$ multishell particles are characteristic for aggregation in buffers of low ionic strength. These particles (fig. 4) consist of a nucleus formed by a viruslike protein shell, and of additional protein layers which surround this nucleus. The thickness of the additional layers is approximately $40 \AA$. A detailed description of the properties of the multishell particles was given recently ${ }^{12}$.

On some electronmicrographs, particles were found which are somewhat different from normal multishell particles (see arrow in fig. 4). These particles which were not observed with protein prepared by the acetic acid method seem to correspond to the laminar aggregates described for protein from cowpea chlorotic mottle virus ${ }^{8}$.

Apart from the laminar aggregates which constitute only a minor fraction of the products of the

15 D. L. D. Caspar and A. Klug, Cold Spring Harbor Sympos. on quantitat. Biol. 27, 1 [1962]. reaggregation process, it is obvious that reaggregation of protein subunits prepared by the use of 2-chloroethanol leads to particles which are identical or at least very similar to those obtained by the acetic acid method. The yield of the reaggregation process and the purity of the protein are also similar in both cases. Thus, splitting the virus by 2-chloroethanol turns out to be a method as suitable for the preparation of $\mathrm{fr}$ protein subunits capable of self-assembly as splitting by acetic acid.

\section{Discussion}

The experiments described above obviously add another proof to the theory that self-assembly is possible for the protein shell of spherical viruses ${ }^{15}$. Furthermore, they, demonstrate that the choice of methods which can be used to achieve self-assembly is not as limited as had been assumed earlier.

The depolymerizing effect of 2-chloroethanol on the fr protein coat may come about through several processes. It was shown that the effect of acetic acid on the same object is mainly caused by the properties of the reagent as an organic solvent, especially by its capability to break hydrophobic bonds, and not by its properties as an acid ${ }^{2}$. This interpretation should be valid also for the effect of 2-chloroethanol. However, since both solvents which can be used for reversible depolymerisation of the fr protein coat are protic, the experiments do not rule out the possibility that for depolymerisation weakening of hydrophobic bonds by the presence of hydrocarbonic groups has to be supported by charge effects produced by low $\mathrm{pH}^{16}$.

The authors wish to express their gratitude for the competent assistance of Mrs. U. Michel and Mr. U. RUDOLPH.

16 P. H. Zahler, D. F. H. Wallach, and E. F. Luescher, Protides of biol. Fluids 15, 69 [1967].
Fig. 1. Virus-like particles, obtained after dialysis of the protein against $1.0 \mathrm{M} \mathrm{NaCl}, 0.02 \mathrm{M}$ phosphate buffer $(\mathrm{pH} 7.6)$. Negative staining with $1 \%(\mathrm{w} / \mathrm{v})$ uranyl-acetate $(\mathrm{pH} 4.4)$.

Fig. 2. Virus-like particles, obtained as in fig. 2. Negative staining with $2 \%(\mathrm{w} / \mathrm{v})$ PTA $(\mathrm{pH} 7.2)$.
Fig. 3. Sedimentation velocity pattern of the sample shown in figs. 1 and 2. The tracing was taken about $14 \mathrm{~min}$ after reaching a rotor speed of $40000 \mathrm{rpm}$.

Fig. 4. Multishell particles, obtained after dialysis of the protein against $0.02 \mathrm{M} \mathrm{NaH} \mathrm{PO}_{4}$. Negative staining with $1 \%$ $(\mathrm{w} / \mathrm{v})$ uranyl-acetate $(\mathrm{pH} 4.4)$. 